\title{
Do Cloacal Pathogenic Microbes Behave as Sexually Transmitted Parasites in Birds?
}

\author{
Aldo Poiani* \\ School of Biological Sciences, Monash University, Victoria 3800, Australia
}

\begin{abstract}
In birds, microparasites found in both the reproductive and the digestive tracts may be transmitted through copulations via cloacal contact (male-to-female and vice versa) and/or through the seminal fluid (mainly male-to-female). Most importantly, such cloacal microparasites are affected by and may in turn affect sexual selection processes and the evolution of mating systems. Here I provide preliminary comparative evidence that at least some cloacal microparasites tend to be distributed in hosts according to the host's mating system and as broadly expected from predictions of sexual selection theory. The patterns, however, are more suggestive than conclusive. There is a non-significant trend for polygamy to be associated with higher richness of cloacal microparasite taxa; with body size, however, also having a positive association with both polygamy and parasite richness. Although increased sexual plumage dichromatism tends to be associated with decreased cloacal microparasite richness, indicating that secondary sexual traits may be used by sexual partners to discriminate between infected and uninfected individuals, qualitative trends also suggest that non-mating periods of the year tend to be associated with slightly higher levels of prevalence and richness of cloacal microparasites. Given this variability of results, it is suggested that future studies should focus on specialist sexually transmitted microbes, to be compared with more generalist one.
\end{abstract}

Keywords: Sexually transmitted microparasites, sexual selection, cloacal microbes.

\section{INTRODUCTION}

In the past two decades or so there has been a significant surge in the interest to study sexually transmitted diseases (STDs) and their causative agents [1]. Although such attention was undoubtedly stirred by the HIV-AIDS pandemic in humans, evolutionary biologists have also started to investigate other systems, both vertebrate and invertebrate, where transmission of pathogens among hosts may occur via sexual intercourse. Evolutionary parasitologists and epidemiologists have made significant inroads into the theoretical and empirical understanding of the behavioural, ecological, lifehistory, immuno-endocrinological, genetic and other mechanisms that drive this specific kind of host-pathogen system. However, our specific knowledge of avian cases remains scanty. I will start this article with a review of the major evolutionary theoretical issues regarding STDs, and then review previous ornithological empirical work carried out on sexually transmissible microbes. I will also describe the results of a comparative analysis which tests some of the major predictions of the hypothesis that at least some cloacal micropathogens behave as sexually transmitted parasites in birds.

\section{STDS IN BIRDS: EVOLUTIONARY DYNAMICS}

Early theoretical modeling of STD transmission (e.g. [2]) identified the basic issues that are relevant to understand whether a sexually-transmitted (ST) pathogen could invade a

*Address correspondence to this author at the School of Biological Sciences, Monash University, Victoria 3800, Australia; Tel: +613 90555769; Fax: +613 99055613; E-mail: Aldo.Poiani@sci.monash.edu.au host population and be maintained over time: a) probability of initial establishment, b) probability of persistence in the host population over the long term, and c) probability of spread to other host populations. Such probabilities are critically dependent on the basic reproductive rate of the infection (Ro), defined as the average number of secondary cases of infection that are produced by a primary case in a susceptible host population. Ro can be calculated as:

$$
\text { Ro }=\beta N /(\alpha+b+v)
$$

where $\alpha=$ virulence, or level of the negative effect of the pathogen on host lifetime reproductive success, $b=$ per capita host death rate in the absence of infection, and $\beta=$ transmission rate, that is the rate of acquisition of the infection by individuals who are susceptible following their contact with an infected individual; $v=$ the recovery rate of infected hosts and $\mathrm{N}$ is the total host population. Ro is therefore calculated as the rate of production of secondary infections by infected individuals per unit time $(\beta \mathrm{N})$, also known as the force of infection, over the average duration of the state of infectiousness $(\alpha+b+v)$ before the host either recovers or dies [3].

A parasite population can be sustained within a population of hosts only if $\mathrm{Ro} \geq 1$. That is, when

$$
\beta N /(\alpha+b+v) \geq 1
$$

From this it follows that the critical host density below which the parasite cannot be sustained in the host population $\left(\mathrm{N}_{\mathrm{T}}\right)$ is:

$$
\mathrm{N}_{\mathrm{T}}=(\alpha+\mathrm{b}+v) / \beta
$$

That is, small populations of hosts can maintain pathogens only if the latter are easily transmitted between hosts 
and/or they are not very harmful to the host (see also [1] and [4]).

If the parasite is sexually transmitted then the criterion for persistence becomes:

$$
\beta\left(m+\sigma^{2} / m\right) /(\alpha+\mathrm{b}+v) \geq 1
$$

where $m=$ mean number of sexual partners per individual and $\sigma^{2}=$ the variance in the number of sexual partners per individual [4].

Therefore, a series of characteristics are displayed by STparasites, with some of those characteristics being shared with other kinds of parasites, whereas others are more specific. ST-pathogens can be maintained in small host populations if they are not highly pathogenic and if they are easily transmitted. Such may be the case in hosts that have a polygamous mating system, as polygamy is associated with higher values of both $m$ and $\sigma^{2}$. In addition, because such parasites are usually transmitted during very restricted and, depending on the host species, relatively infrequent circumstances (i.e. when their hosts mate), they are expected to evolve strategies to escape the immune system of the host over a relatively long period of time; possessing intracellular stages of development may help the parasite achieve this [5]. Such parasites are also expected to have lower negative effects, and perhaps higher positive effects, on those specific traits that facilitate sexual intercourse in the host [5]. If the parasite has to spend a long time dormant in the host and be dependent on good host health for successful sexual transmission, then its effects on the host's health may be expected to be relatively mild especially in systems where hosts exert strong pre-mating sexual partner choice and discrimination. Countering this, high rates of transmission are expected to be correlated with the evolution of virulence in the parasite, which leads to the prediction that mating systems characterised by promiscuity, low degree of discrimination between alternative sexual partners and higher rates of sexual intercourse per partner are expected to favour the evolution of highly pathogenic ST-parasites [5]. High virulence is also expected to evolve in the case of multiple infections, where parasites may engage in interspecific competition within the host (e.g. [6]) or, in a more synergistic scenario, when the probability of infection by a second kind of parasite is enhanced by current infection [7].

Because ST-pathogens are transmitted between individuals following processes of mate choice and opportunities to access mates willing to copulate, the density of infectious individuals in the population is not as important for the transmission of STDs as for other kinds of diseases (e.g. those caused by airborne viruses) [4,7]. Instead, STD transmission is more dependent on the frequency of infectives [8] and also copulation rate both with the same and also with various sexual partners $[9,10]$ as suggested above.

Parasites and hosts are usually engaged in coevolutionary processes where both exert selective pressures on each other. I have already mentioned that in the case of STDs, parasite transmission and the evolution of virulence are influenced by the host mating system; and the evolution of host mating strategies, in turn, is influenced by sexually transmitted parasites [11, 12]. Sexual selection, for instance, can decrease the evolution of virulence among ST-parasites [13], simply because if secondary sexual traits are costly (sensu Zahavi [14]) then virulent parasites would be associated with development of less attractive secondary sexual traits in the host, and therefore lower probability of mating. As mating rates decrease, probability of transmission of the ST-parasite will also decrease. Thrall et al. [15] have predicted that when prevalence of ST-pathogens is relatively low or intermediate in the host population, then discrimination of sexual partners within a polygamous mating system and/or monogamy should be selected. In the absence of STDs, promiscuity can be selected. Interestingly, if the prevalence of ST-pathogens is very high promiscuity can also be selected ([15], see also [16]) as at high prevalence values for the parasite the probability of being infected does not decrease significantly by mating with fewer partners.

Whereas hosts are under selective pressure to discriminate between sexual partners (assortative mating) in order to decrease ST-pathogen transmission (e.g. [16,17]), those pathogens, in turn, are under selective pressure to enhance sexual attractiveness and/or sexual activity of their hosts which may increase their chances of transmission [18]. It can be easily seen how this situation can jump start a runaway sexual selection process whereby parasites enhance the attractiveness of male birds whereas females become more discriminative, which may result in the prevention of infection [19]; parasites will then be selected to further increase attractiveness of males in order to overcome female choosiness. A similar mechanism is involved in the Chase Away sexual selection model of Holland and Rice [20] in which female avoidance of costs of mating (STDs in our case) may sustain a runaway evolutionary process for attractive males exploiting sensory preferences of females and for females to be reluctant to mate with showy males. A slight variation on this theme was proposed by Graves and Duvall [21] who suggested that female preference for more attractive males may increase the probability of transmission of STDs thus lowering female fitness. This would result in selection on females to preferentially choose males with less attractive secondary sexual traits, such a preference would be associated with higher fitness and, with time, lowered STD transmission [e.g. 156]. However, as prevalence of ST-pathogens decreases in the host population sexual selection may increase for males displaying more conspicuous secondary sexual traits, and so the cycle will start again.

Interestingly, such coevolutionary cycles based on negative feedback may be broken if the parasite and the host evolve a symbiotic mutualistic relationship, where the sexually transmissible microbe may increase its spread in the host population by a) decreasing its pathogenicity, b) increasing the attractiveness of honest secondary sexual traits and also c) increasing both male and female host's mating and reproductive success. However, such a mutualistic system can be evolutionary stable only if there is strong competition between cloacal microorganisms, and a new pathogenic mutant or invader has little chance of succeeding within a host that already carries a predominantly mutualistic cloacal microflora.

STDs can not only affect male-female mating interactions, but they may even affect sperm competition among males. For instance, an immunoreactive female reproductive tract that is competent in the defence against micropathogens carried by the semen, may also produce an immune attack 
against spermatozoa thus exerting a selective pressure on ejaculates from different males, such selective pressure may affect the outcome of sperm competition (see [22, 23] and refs. therein).

\section{STDS IN BIRDS: A REVIEW OF EMPIRICAL STUD- IES}

Both the avian cloaca and various sections of the reproductive and digestive systems, harbour a large variety of microorganisms that could be eventually transferred from one individual to another during copulation. Most male birds do not possess penile-like organs that are intromitted into the female cloaca during copulation, hence female-to-male transfer of ST-pathogens is only likely to occur through infection of the external surface of the female cloaca and the fluids that cover it. Male-to-female transfer of ST-pathogens, however, can also occur through contamination of the semen. Therefore in birds there is a likely bias in the transmission rate of ST-parasites from male to female. This has been recently demonstrated by Kulkarni and Heeb [24] in Taeniopygia guttata. Birds, both males and females, had their cloaca experimentally infected with Bacillus licheniformis. This allowed the measurement of the level of symmetry between male-to-female and female-to-male transmission. What Kulkarni and Heeb found was that the rate of transmission was higher from male to female than vice versa.

The avian semen may contain a diverse microflora that originates from various sections of the reproductive but to some extent also the digestive tract, as the cloaca is a common route of discharge of both faeces and seminal products.

Table 1 summarises the findings of some of the works that have studied seminal microflora in birds. Microorganisms in Table $\mathbf{1}$ are broadly classified as viruses, bacteria or fungi, the latter encompassing a diversity of taxa that include yeast, mould and others [34]. Although studies of seminal microflora are mainly confined to a few species, with emphasis on domestic birds, it is clear that many kinds of micropathogens could be transmitted through the semen during copulation. That some of those pathogens may be specialists on the reproductive system, but many others may originate from the digestive system was shown by Hupton et al. [31] who reported the prevalence of various microbes in both the cloaca and the seminal fluid in Agelaius phoeniceus. Although the trend was for prevalence in the cloaca to be positively correlated with prevalence in the semen, the association was not statistically significant presumably reflecting the binary origin of the cloacal microflora.

In taxa that possess a phallus (e.g. Anseriformes) STDs could be also transmitted from female to male. In fact, various microorganisms such as Candida albicans and Mycoplasma that inhabit the cloaca can infect the phallus of domestic geese (e.g. [35-37]).

After copulation has occurred, the success or failure of sexually transmitted micropathogens to establish themselves in the host and perhaps cause disease, is likely to be a complex process. Factors of potential importance include current parasitic loads in the sexual partners and how within-host pathogen community structure influences competitive exclusion or coexistence or even facilitation of the various species or strains. Of clear importance is the ability of individual host defence systems (e.g. immunity) to clear the body of invading pathogens which will be determined by host genotype as well as condition (i.e. general health). Such considerations may explain why, for instance, the level of congruence in bacterial presence or absence between mated individuals is not necessarily perfect (e.g. $36 \%$ in Hupton et al.'s [31] study of Agelaius phoeniceus), although additional effects such as extra-pair copulations may also decrease the level of intra-pair similarity.

Understanding the microflora composition of the avian semen is critical in order to unravel the mechanisms of sexual transmission of pathogens, however a broader knowledge of the cloacal microflora is also of great potential relevance. The cloacal microflora may have diverse origins within the body of the animal: faeces and reproductive system as mentioned above, but also skin and feathers from the regions surrounding the cloacal opening (e.g. [38]) and it may be affected by a variety of factors that range from genetic makeup, immune competence, body size, age and sex of the host to host population density, host habitat, food and more. The cloacal microflora is acquired very early on by young birds from their environment (e.g. [39]) and whether cloacal microorganisms persist or not in the host is critically dependent on both the host's immune system (e.g. [40]) and ecological interactions among the various microbes (e.g. [41]). Moreover, sexual transmission is not only restricted to microorganisms. Some arthropod ectoparasites such as Menapon and Goniodes feather lice may also be transmitted during copulation [42].

I have mentioned in the previous section that the ecology of the cloacal microflora, as expressed through inter-specific interactions between diverse kinds of microorganisms, can play a major role in shaping the species composition of within-host microbe communities: what kind of pathogen that was acquired through copulation will be able to survive and establish itself in the new environment and therefore what kind of pathogen will be in turn transmitted in future copulations. Being infected by more than one pathogen (i.e. superinfection) may result in decreased host fitness if pathogens have synergistic negative effects on the host. For instance, Chlamydophila infected turkeys may suffer greater deterioration of their health when superinfected with Escherichia coli [43]. Similarly, Newcastle Disease virus titres increased in chickens following superinfection with $E$. coli [44]. However STD-microbes may be also involved in competitive interactions among themselves. At one end of the spectrum of possibilities, one sexually transmissible pathogen may outcompete others (e.g. Enterococcus faecalis may outcompete other species of Enterococcus in pied flycatcher, Ficedula hypoleuca, [45]). At the other end of the spectrum harmless microbes may defend the organism against infections by pathogenic microbes, thus becoming, overall, beneficial to their host. Lactobacillus is an example of such "probiotic" bacteria which has been studied in many birds [30, $46,47]$. Bacillus subtilis is another probiotic bacterium able to outcompete E. coli, Salmonella enterica and Clostridium perfringens in chickens [48, 49].

In this work I test the hypothesis that cloacal pathogenic microorganisms are distributed across host species in a manner that is expected from them being sexually transmitted parasites. This hypothesis predicts that the more polygamous 
Table 1. Some Micropathogens that have been Isolated from Avian Semen

\begin{tabular}{|c|c|c|}
\hline VIRUSES & & \\
\hline Taxon & $\underline{\text { Host }}$ & $\underline{\text { Reference }}$ \\
\hline Chicken anaemia virus & Gallus domesticus & {$[25]$} \\
\hline Avian influenza virus & Meleagris gallopavo & [26] \\
\hline \multicolumn{3}{|l|}{ BACTERIA } \\
\hline Mycoplasma spp. & Meleagris gallopavo & [27] \\
\hline M. gallisepticum & Anser anser & [28] \\
\hline M. meleagridis & Meleagris gallopavo & [29] \\
\hline Salmonella spp. & Tachycineta bicolor & {$[30]$} \\
\hline Shigella spp. & Tachycineta bicolor & [30] \\
\hline Vibrio spp. & Tachycineta bicolor & {$[30]$} \\
\hline Parahaemolyticus spp. & Tachycineta bicolor & {$[30]$} \\
\hline Yersinia spp. & Tachycineta bicolor & {$[30]$} \\
\hline Bacillus circulans & Agelaius phoeniceus & {$[31]$} \\
\hline B. laterosporus & Agelaius phoeniceus & [31] \\
\hline B. licheniformis & Agelaius phoeniceus & {$[31]$} \\
\hline Enterobacter agglomerans & Agelaius phoeniceus & {$[31,32]$} \\
\hline E. cloacae & Agelaius phoeniceus & [31] \\
\hline Enterococcus gallinarum & Agelaius phoeniceus & [31] \\
\hline Escherichia coli & Agelaius phoeniceus & [31] \\
\hline Gardnerella vaginalis & Agelaius phoeniceus & [31] \\
\hline Listeria spp. & Agelaius phoeniceus & {$[31]$} \\
\hline L. denitrificans & Agelaius phoeniceus & [31] \\
\hline L. grayi & Agelaius phoeniceus & [31] \\
\hline Micrococcus spp. & Agelaius phoeniceus & {$[31]$} \\
\hline M. roseus & Agelaius phoeniceus & [31] \\
\hline Staphylococcus cohnii & Agelaius phoeniceus & [31] \\
\hline S. epidermis & Agelaius phoeniceus & [31] \\
\hline S. warneii & Agelaius phoeniceus & [31] \\
\hline S. xylosus & Agelaius phoeniceus & [31] \\
\hline Acinetobacter calcoaceticus & Agelaius phoeniceus & [32] \\
\hline Pseudomonas spp. & Agelaius phoeniceus & {$[32]$} \\
\hline P. putida & Agelaius phoeniceus & [32] \\
\hline P. paucimobilis & Agelaius phoeniceus & [32] \\
\hline P. maltophila & Agelaius phoeniceus & [32] \\
\hline Ewingella americana & Agelaius phoeniceus & [32] \\
\hline
\end{tabular}


Table 1. contd...

\begin{tabular}{|c|c|c|}
\hline BACTERIA & & \\
\hline$\underline{\text { Taxon }}$ & $\underline{\text { Host }}$ & $\underline{\text { Reference }}$ \\
\hline \hline Aeromonas hydrophila & Agelaius phoeniceus & Agelaius phoeniceus \\
\hline Weeksella virosa & & {$[32]$} \\
\hline FUNGI & & Anser anser \\
\hline
\end{tabular}

and also the more sexually dichromatic species are likely to harbour more cloacal microparasites if parasitism is a cost of multiple matings, but those host species should harbour less cloacal microparasites if mate choice mechanisms, based on secondary sexual traits, are in place that are used to select for less parasitised sexual partners. Moreover, the cloaca is expected to host more microparasites during the breeding than during the non-breeding periods of the year. The test will be done by means of carrying out a comparative analysis across 56 bird taxa pertaining to 10 orders.

\section{MATERIALS AND METHODS}

Data used in the comparative analyses were obtained from published works after a thorough bibliographical search was carried out through the Web of Science, Google Scholar, Biological Abstracts, Scopus, ProQuest and list of references taken from review articles. I was able to obtain information for a sufficient number of host species for seven variables associated directly or indirectly with reproductive behaviour (climate, time of sampling, sex of host, age of host, mating system, extra-pair copulations (EPCs) and sexual dichromatism), and two dependent variables that measure cloacal parasitism: taxa richness and mean value of prevalence, the latter being the sum of prevalence values for the parasitic taxa found in a host species divided by the number of those parasitic taxa. Host body mass (in grams) was also recorded and the value entered was the log-transformed mean value of body mass of male and female. Only values of the parasitological variables recorded from host sample sizes larger or equal than 10 were included in the analyses.

Climate data were inferred according to the study region mentioned in the original source data using the KöppenGeiger climate classification system [50]. The following climates were represented in our sample (Köppen-Geiger code in parenthesis): semi-arid (Bsh, Bsk), humid subtropical (Cfa), oceanic (Cfb), mediterranean (Csa), humid continental (Dfa, Dfb, Dwb), subarctic (Dfc), polar (Ef). Each climate is characterised by a categorisation of the level of humidity (high, medium and low) and temperature (high, medium and low). Time of sampling of parasites could be during the breeding or during non-breeding periods of the population studied. Some studies, however reported results of year-round sampling. Sex of the host was also recorded, whether it was male or female, although most entries from the literature corresponded to combined values of parasitism for both sexes. Age of the host (adult vs. young) was also recorded. Mating system ranged from monogamy (M), facultative polygyny (FPy), polygyny (Py) and polyandry (Pa) to polygamy $(\mathrm{Pm})$ and promiscuity $(\mathrm{Pr})$. The "EPCs" category actually included a variety of variables ranging from actual EPC to extra-pair paternity (EPP) and forced-EPCs (FEPC). These variables are different and cannot be directly combined in the same analysis. However, in order to use all of the information available and yet account for the difference between variables, I ordered the data into broad categories: No EPC (or EPP, FEPC) (0\%), Low (>0\%-3\%), Medium $(>3 \%-10 \%)$, High $(>10 \%-40 \%)$, Very High $(>40 \%)$. Sexual dichromatism was measured in terms of marked plumage colouration differences between males and females and recorded as either present or absent.

With regard to cloacal parasites, they are reported in the literature at various levels of taxonomic identification: genus, species, but also broader descriptions such as "anaerobic bacteria". I measured richness as the number of different taxa recorded. For each study published on a specific host species, I also calculated the mean prevalence (percentage of hosts infected) across parasite taxa and averaged values across studies in order to obtain a mean value of prevalence of infection for each host species. In this way I smoothed the effect of the high variability in prevalence values usually found in parasitological studies, and hence decreased the effect of outliers. Studies report values of prevalence for viruses, bacteria and fungi, which in this case were combined in the analyses to provide an overall value of microparasitic richness and mean prevalence in the cloaca.

I tested the hypothesis by carrying out comparative analyses using independent contrasts [51]. "Time of sampling", however was a variable analysed through a Wilcoxon two-sample test, whereas sex of the host was not included in the analyses due to most authors lumping together the information for males and females. Most studies also focus on adults, thus limiting our ability to test for age effects across species. Calculation of phylogenetically independent contrasts was carried out using the PDAP program [52] that runs in the Mesquite program of Maddison and Maddison [53]. All analyses used branch lengths set following Grafen's method [54].

The 56 taxa included in the analyses pertain to the orders: Anseriformes, Galliformes, Sphenisciformes, Ciconiiformes, Gruiformes, Charadriiformes, Strigiformes, Falconiformes, Columbiformes and Passeriformes. In the comparative analysis, I used a compound phylogeny of those taxa (see 


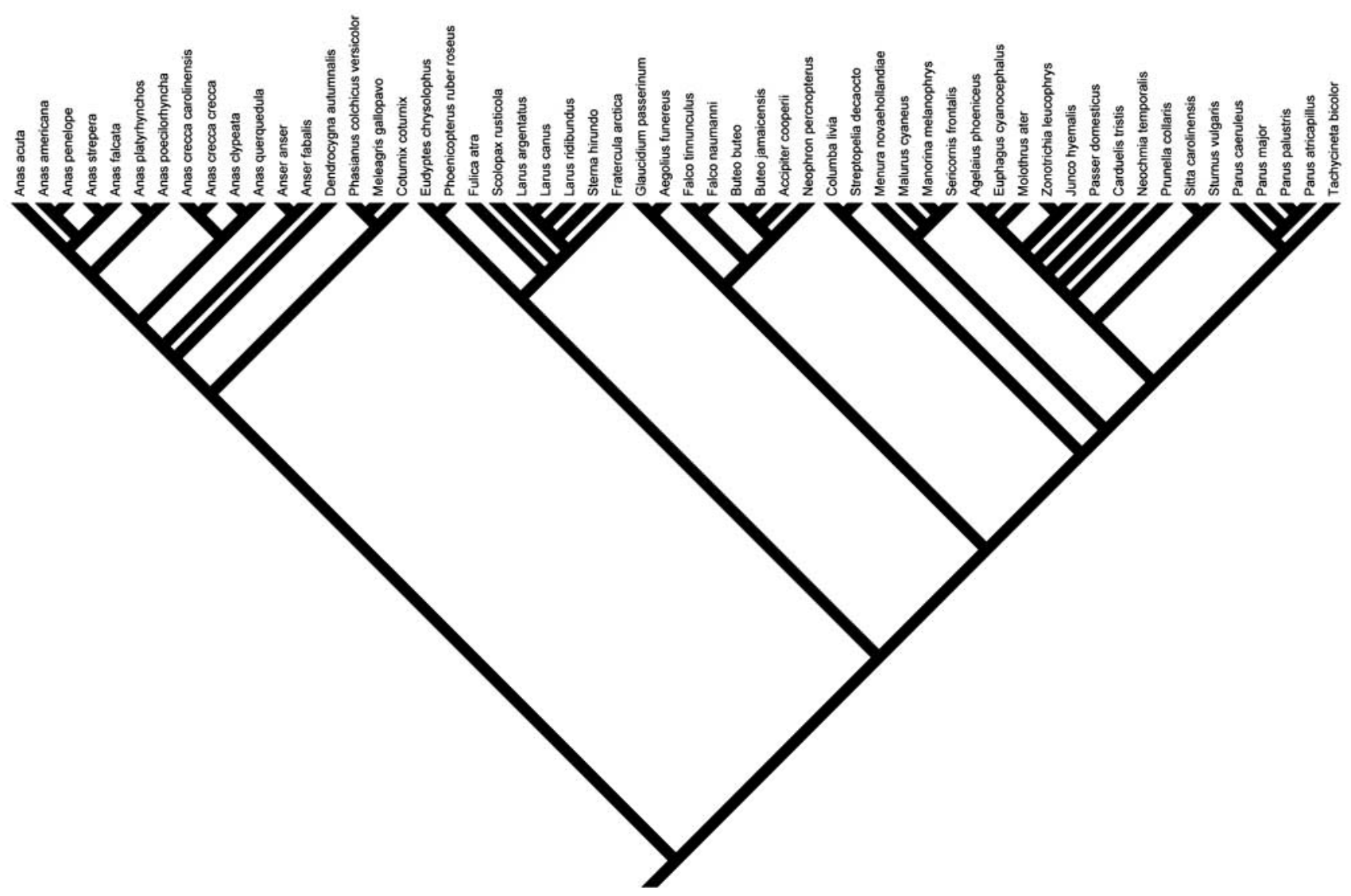

Fig. (1). Compound phylogeny of the 56 bird taxa used in the comparative analyses.

Fig. 1) that was reconstructed on the basis of the following published information. The phylogenetic relationship among orders was based on Livezey and Zusi [55]. This order-level phylogeny allowed the easy positioning of taxa represented by only one or only two species within the phylogeny. Orders represented by more than two species required a more detailed within-order phylogeny. The phylogeny of the Anseriformes was reconstructed on the basis of Johnson and Sorenson [56] and Donne-Goussé et al. [57]. The Galliformes phylogeny followed Kimball and Braun [58], whereas the Charadriiformes' was based on Paton et al. [59] and Thomas et al. [60]. The Falconiformes followed Lerner and Mindell [61] and, finally, the specific phylogeny of the Passeriformes was reconstructed using information from various authors [62-72].

Continuous variables such as body mass and prevalence were log- and square-root (plus one)-transformed respectively before they were entered in the analyses. Categorical variables were coded in the following manner. Mating system: $\mathrm{M}=1$, FPy $=2, \mathrm{Py}, \mathrm{Pa}=3, \mathrm{Pm}, \mathrm{Pr}=4$; "EPCs": No EPCs $=1$, Low $=2$, Medium $=3$, High $=4$ and Very High $=$ 5; Plumage Sex Dichromatism: Monochromatic = 1, Dichromatic $=2$; Climate: each climate type was categorised high (3), medium (2), or low (1) in terms of temperature and humidity. The scores for temperature and humidity were then added to provide an overall code for each climate. These combined codes increased from Polar/Sub-arctic (2) to Humid Continental (3), Mediterranean/Semi-arid (4) to Oceanic (5) and Humid Subtropical (6) climates.
Finally Pearson's product-moment correlations were carried out between variables expressed as phylogenetically independent contrasts.

\section{RESULTS}

The full original dataset used in the comparative analyses is shown in Table 2 . For each variable only one value was entered for each bird species - after transformation or encoding as the case may be - by obtaining the mean value for the various intra-specific data. Table $\mathbf{3}$ summarises the cloacal microorganism taxa found in the various studies. The results of relevant correlations between phylogenetically independent contrasts are shown in Table 4. The first result that I would like to highlight is the significant trend for evolutionary changes towards increased richness of cloacal microparasites to be associated with evolutionary changes towards living in more tropical climates. Prevalence contrasts, on the other hand, are not significantly associated with climate contrasts and, if anything, the trend is for decreased prevalence of cloacal microparasites as hosts tend to live in more tropical climates. Therefore, although in tropical climates there is a larger number of cloacal microparasite taxa, the level of infection is not necessarily higher than in non-tropical climates.

I also detected a highly significant positive correlation between log-body mass contrasts and mating system contrasts, indicating that evolutionary trends towards larger body sizes are associated with evolutionary trends toward a higher degree of polygamy. Moreover, as the body size tends 
Table 2.

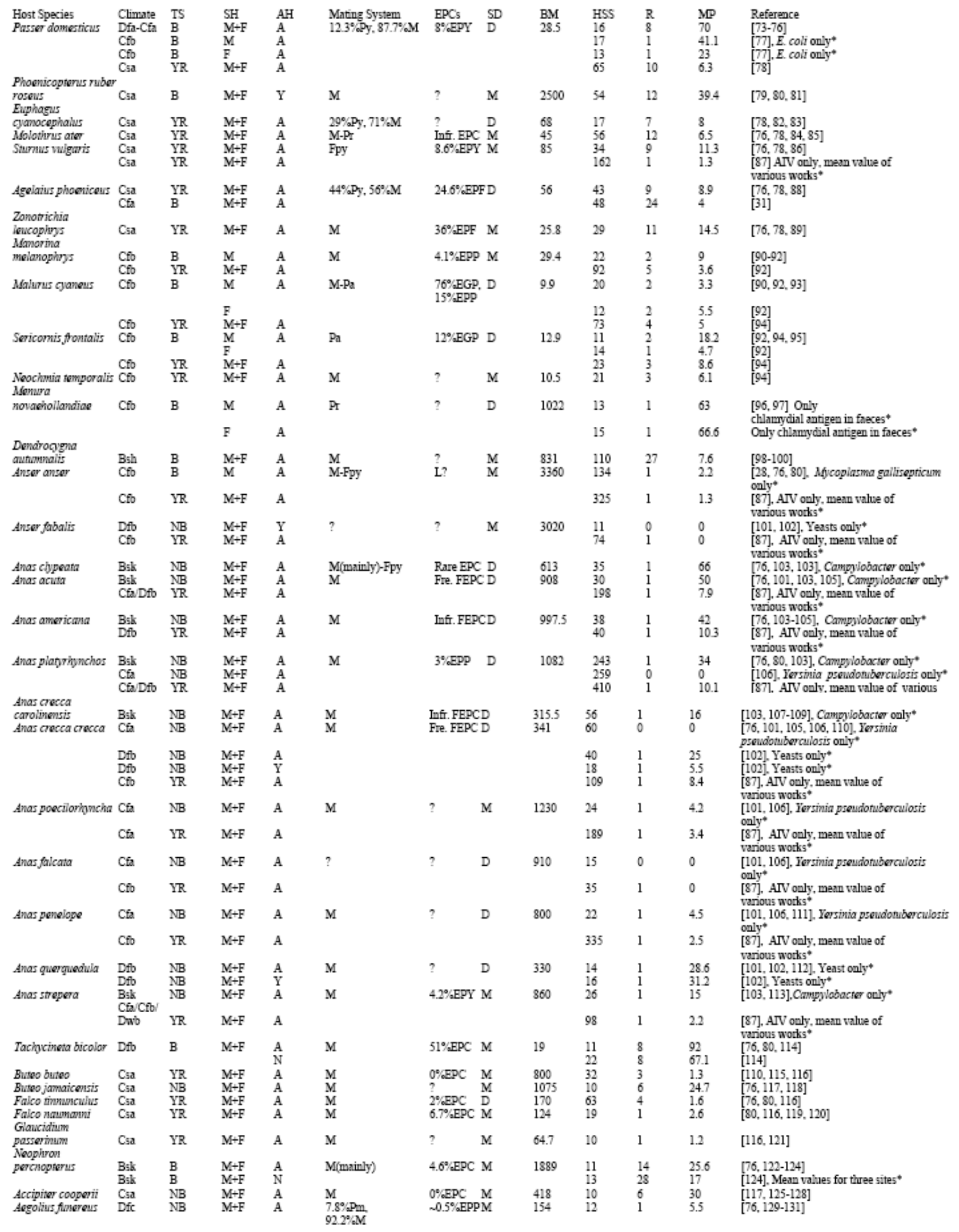


Table 2. contd...

\begin{tabular}{|c|c|c|c|c|c|c|c|c|c|c|c|c|}
\hline \multirow[t]{2}{*}{$\begin{array}{l}\text { Fratercula arctica } \\
\text { Lanus argentans }\end{array}$} & $\begin{array}{l}\text { Dfc } \\
\text { Dfic }\end{array}$ & $\begin{array}{l}\mathrm{NB} \\
\mathrm{NB}\end{array}$ & $\begin{array}{l}\mathrm{M}+\mathrm{F} \\
\mathrm{M}+\mathrm{F}\end{array}$ & A & \multirow{2}{*}{$\begin{array}{l}\text { M } \\
76.9 \% \text { Py. } \\
23.1 \% \mathrm{M}\end{array}$} & \multirow{2}{*}{\multicolumn{2}{|c|}{$\begin{array}{l}\text { Infr. } \mathrm{EPC} \mathrm{M} \\
0.5 \% \mathrm{EPC} \mathrm{M}\end{array}$}} & \multirow[t]{2}{*}{$\begin{array}{l}490.5 \\
1025\end{array}$} & $\begin{array}{l}76 \\
24\end{array}$ & $\begin{array}{l}1 \\
2\end{array}$ & $\begin{array}{l}17.1 \\
2.7\end{array}$ & \multirow{2}{*}{$\begin{array}{l}{[76,129,132]} \\
{[76,80,129]} \\
{[87], \text { AIV only, menn value of }}\end{array}$} \\
\hline & $\mathrm{Dfb}$ & YR & $\mathrm{M}+\mathrm{F}$ & A & & & & & 153 & 1 & 2.1 & \\
\hline Lanus canus & $\begin{array}{l}\text { Dfic } \\
\text { Dfb }\end{array}$ & $\begin{array}{l}\text { NB } \\
\text { YR }\end{array}$ & $\begin{array}{l}\mathrm{M}+\mathrm{F} \\
\mathrm{M}+\mathrm{F}\end{array}$ & $\begin{array}{l}\text { A } \\
\text { A }\end{array}$ & $\mathrm{M}$ & $3.6 \% \mathrm{EPF}$ & M & 432 & $\begin{array}{l}37 \\
275\end{array}$ & $\begin{array}{l}1 \\
1\end{array}$ & $\begin{array}{l}6.3 \\
0\end{array}$ & $\begin{array}{l}{[76,129,133]} \\
\text { [87], AIV only, menn value of }\end{array}$ \\
\hline Lanus nidibundus & $\begin{array}{l}\text { Dfic } \\
\text { Cfa }\end{array}$ & $\stackrel{\mathrm{NB}}{\mathrm{NB}}$ & $\begin{array}{l}\mathrm{M}+\mathrm{F} \\
\mathrm{M}+\mathrm{F}\end{array}$ & A & M & $?$ & $\mathrm{M}$ & 260 & $\begin{array}{l}53 \\
20\end{array}$ & ${ }_{0}^{2}$ & $\begin{array}{l}5 \\
0\end{array}$ & $\begin{array}{l}{[76,110,129]} \\
{[106], \text { Yersinia pseudonberculosis only* }}\end{array}$ \\
\hline & $\mathrm{Cfb}$ & YR & $\mathrm{M}+\mathrm{F}$ & A & & & & & 256 & 1 & 17.7 & $\begin{array}{l}\text { [87], AIV ouly, memn value of } \\
\text { various wotks" }\end{array}$ \\
\hline Stema hinudo & $\begin{array}{l}\text { Dfc } \\
\text { Dfb }\end{array}$ & $\begin{array}{l}\mathrm{NB} \\
\mathrm{YR}\end{array}$ & $\begin{array}{l}\mathrm{M}+\mathrm{F} \\
\mathrm{M}+\mathrm{F}\end{array}$ & $\begin{array}{l}\text { A } \\
\text { A }\end{array}$ & M & $2.6 \% \mathrm{EPC}$ & M & 120 & $\begin{array}{l}36 \\
240\end{array}$ & $\begin{array}{l}2 \\
1\end{array}$ & $\begin{array}{l}2.7 \\
1.9\end{array}$ & $\begin{array}{l}{[76,129,134,135]} \\
{[87], \text { AIV only, menn value of }} \\
\text { various works" }\end{array}$ \\
\hline $\begin{array}{l}\text { Prunella collanis } \\
\text { Panus caeruleus } \\
\text { Parus major } \\
\text { Panus palustis } \\
\text { Parns aricapillus } \\
\text { Jinco hemalis }\end{array}$ & $\begin{array}{l}\text { Dfb } \\
\text { Dfb } \\
\text { Dfb } \\
\text { Dfb } \\
\text { Dfb } \\
\text { Dfb } \\
\text { Dfb }\end{array}$ & $\begin{array}{l}\mathrm{YR} \\
\mathrm{NB} \\
\mathrm{NB} \\
\mathrm{NB} \\
\mathrm{NB} \\
\mathrm{NB} \\
\mathrm{YR}\end{array}$ & $\begin{array}{l}\mathrm{M}+\mathrm{F} \\
\mathrm{M}+\mathrm{F} \\
\mathrm{M}+\mathrm{F} \\
\mathrm{M}+\mathrm{F} \\
\mathrm{M}+\mathrm{F} \\
\mathrm{M}+\mathrm{F} \\
\mathrm{M}+\mathrm{F}\end{array}$ & $\begin{array}{l}\mathrm{A}+\mathrm{J} \\
\mathrm{A} \\
\mathrm{A} \\
\mathrm{A} \\
\mathrm{A} \\
\mathrm{A} \\
\mathrm{A}\end{array}$ & $\begin{array}{l}\mathrm{Pa} \\
6 \% \mathrm{Py}, 94 \mathrm{M} \\
\mathrm{M} \\
\mathrm{M} \\
\mathrm{M} \\
\mathrm{M}\end{array}$ & $\begin{array}{l}0 \% \text { EPO } \\
10.9 \% \mathrm{EPC} \\
7.3 \% \mathrm{EPO} \\
? \\
8.9 \% \mathrm{EPO} \\
25 \% \mathrm{EPP}\end{array}$ & $\begin{array}{l}\mathrm{M} \\
O D \\
\mathrm{D} \\
\mathrm{M} \\
\mathrm{M} \\
\mathrm{D}\end{array}$ & $\begin{array}{l}37.5 \\
10.6 \\
17.3 \\
12 \\
10.4 \\
19\end{array}$ & $\begin{array}{l}28 \\
43 \\
318 \\
32 \\
290 \\
40 \\
15\end{array}$ & $\begin{array}{l}11 \\
1 \\
1 \\
1 \\
5 \\
3 \\
1\end{array}$ & $\begin{array}{l}6.5 \\
69.8 \\
53.1 \\
37.5 \\
10.1 \\
6.6 \\
6.6\end{array}$ & 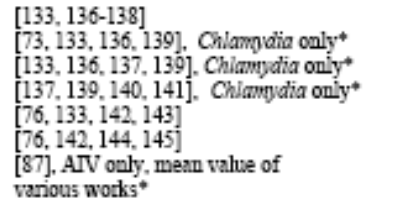 \\
\hline $\begin{array}{l}\text { Carduelis tristis } \\
\text { Simta carolinensis } \\
\text { Phasianus colchicus }\end{array}$ & $\begin{array}{l}\text { Dfb } \\
\text { Dfb }\end{array}$ & $\stackrel{\mathrm{NB}}{\mathrm{NB}}$ & $\begin{array}{l}\mathrm{M}+\mathrm{F} \\
\mathrm{M}+\mathrm{F}\end{array}$ & A & $\stackrel{M}{M}$ & $14.3 \%$ EPC & $\begin{array}{l}O D \\
D\end{array}$ & $\begin{array}{l}13.6 \\
20\end{array}$ & $\begin{array}{l}25 \\
19\end{array}$ & $\begin{array}{l}3 \\
4\end{array}$ & ${ }_{123}^{4}$ & $\begin{array}{l}{[76,133,142]} \\
{[76,142]}\end{array}$ \\
\hline versicolor & $\mathrm{Cfa}$ & NB & $\mathrm{M}+\mathrm{F}$ & A & Py & $6 \% \mathrm{EPp}$ & D & 1600 & 13 & 0 & 0 & $\begin{array}{l}\text { [106, 146-148], Yersinia psoudotuberculosis } \\
\text { only* }\end{array}$ \\
\hline $\begin{array}{l}\text { Meleagris gallopano } \\
\text { Columba livia }\end{array}$ & $\begin{array}{l}\text { Bak } \\
\text { Bak } \\
\text { Bak } \\
\text { Bak } \\
\text { Cfa }\end{array}$ & $\begin{array}{l}\mathrm{NB} \\
\mathrm{NB} \\
\mathrm{B} \\
\mathrm{YR} \\
\mathrm{YR}\end{array}$ & $\begin{array}{l}\mathrm{M}+\mathrm{F} \\
\mathrm{M}+\mathrm{F} \\
\mathrm{M}+\mathrm{F} \\
\mathrm{M}+\mathrm{F} \\
\mathrm{M}+\mathrm{F}\end{array}$ & $\begin{array}{l}\text { A } \\
\text { A } \\
\text { A } \\
\text { A } \\
\text { A }\end{array}$ & $\begin{array}{l}\mathrm{py} \\
\mathrm{M}\end{array}$ & $?$ & $\begin{array}{l}M \\
D\end{array}$ & $\begin{array}{l}7300 \\
358.7\end{array}$ & $\begin{array}{l}190 \\
200 \\
200 \\
400 \\
47\end{array}$ & $\begin{array}{l}1 \\
1 \\
1 \\
4 \\
1\end{array}$ & $\begin{array}{l}25 \\
31 \\
21.5 \\
7 \\
0\end{array}$ & 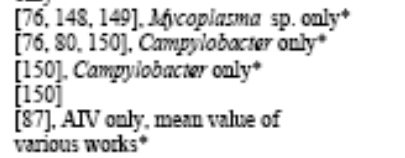 \\
\hline Streptopelia decaocto & $\begin{array}{l}\text { Dfb } \\
\text { Dfb } \\
\text { Dfb }\end{array}$ & $\begin{array}{l}\mathrm{NB} \\
\mathrm{NB} \\
\mathrm{YR}\end{array}$ & $\begin{array}{l}\mathrm{M}+\mathrm{F} \\
\mathrm{M}+\mathrm{F} \\
\mathrm{M}+\mathrm{F}\end{array}$ & $\begin{array}{l}\mathrm{A} \\
\mathrm{Y} \\
\mathrm{A}\end{array}$ & $\mathrm{M}$ & ? & M & 187 & $\begin{array}{l}50 \\
54 \\
19\end{array}$ & $\begin{array}{l}1 \\
1 \\
1\end{array}$ & $\begin{array}{l}8 \\
6.2 \\
5.2\end{array}$ & $\begin{array}{l}\text { [102, 148, 151], Yeasts only* } \\
{[102], \text { Yensts only }} \\
\text { [87], AIV only, mean value of } \\
\text { vanious works }\end{array}$ \\
\hline $\begin{array}{l}\text { Scolopax nusticola } \\
\text { Conumix conminx }\end{array}$ & $\begin{array}{l}\text { Dfb } \\
\text { Dfb } \\
\text { Dfb } \\
\text { Dfb } \\
\text { Cfa }\end{array}$ & $\begin{array}{l}\mathrm{NB} \\
\mathrm{NB} \\
\mathrm{NB} \\
\mathrm{NB} \\
\mathrm{YR}\end{array}$ & $\begin{array}{l}\mathrm{M}+\mathrm{F} \\
\mathrm{M}+\mathrm{F} \\
\mathrm{M}+\mathrm{F} \\
\mathrm{M}+\mathrm{F} \\
\mathrm{M}+\mathrm{F}\end{array}$ & $\begin{array}{l}\mathrm{A} \\
\mathrm{Y} \\
\mathrm{A} \\
\mathrm{Y} \\
\mathrm{Y}\end{array}$ & $\begin{array}{l}\mathrm{Py} \\
\mathrm{Pm}\end{array}$ & $\begin{array}{l}? \\
26 \% \mathrm{EPP}\end{array}$ & M & $\begin{array}{l}309 \\
112.5\end{array}$ & $\begin{array}{l}43 \\
62 \\
29 \\
28 \\
145\end{array}$ & $\begin{array}{l}1 \\
1 \\
0 \\
1 \\
1\end{array}$ & $\begin{array}{l}9.3 \\
1.6 \\
0 \\
3.4 \\
0\end{array}$ & $\begin{array}{l}\text { [102, 152], Yeasts only* } \\
\text { [102], Yensts only* } \\
\text { [76, 102, 153], Yensts only* } \\
\text { [102], Yeasts only* } \\
\text { [87], ANV ouly, menn value of } \\
\text { various wotks }\end{array}$ \\
\hline Fulica atra & $\begin{array}{l}\text { Dfb } \\
\mathrm{Cfa} \cdot \mathrm{Dfb}\end{array}$ & $\begin{array}{l}\mathrm{NB} \\
\mathrm{YR}\end{array}$ & $\begin{array}{l}\mathrm{N}+\mathrm{F} \\
\mathrm{N}+\mathrm{F}\end{array}$ & $\begin{array}{l}\mathrm{Y} \\
\mathrm{Y}\end{array}$ & $\mathrm{M}$ & $?$ & $\mathrm{M}$ & 735.3 & $\begin{array}{l}42 \\
445\end{array}$ & $\begin{array}{l}1 \\
1\end{array}$ & $\begin{array}{l}59.5 \\
1.8\end{array}$ & $\begin{array}{l}\text { [102, 154], Yeasts only }{ }^{*} \\
\text { [87], ATV only, menn value of } \\
\text { various wotks }\end{array}$ \\
\hline $\begin{array}{l}\text { Eudyptes } \\
\text { chrysolophus }\end{array}$ & Ef & B & $\mathrm{M}+\mathrm{F}$ & $\mathrm{Y}$ & $\mathrm{M}$ & ? & $\mathrm{M}$ & 5500 & 100 & 1 & 3 & $\begin{array}{l}\text { [76, 148, 155], Campylabacter jeyjuni } \\
\text { sabsp. jewiuni only }\end{array}$ \\
\hline
\end{tabular}

${ }^{*}=$ Valve of richness not used in the avalyses as the study only targeted one specific pathogen. $T S=$ Time of sampling: $B$ (breeting), YR (year round), $\mathrm{NB}$ (non-breeding). SH $=\mathrm{Sex}$ of host. AH $=$ Age of host: A (adult). Y (young). J (juvenile), N (nesting). SD = Sexual plumage dichromatism: $\mathrm{M}$ (monochromatic). D (dichromatic). BM = Body mass in grams. HSS = Host sample size, Inf. = infrequent, Fre. $=$ freguent. $R=$ parasite species richness. $M P=$ mean value of prevalence $(\%)$.

to increase, microparasite richness also tends to increase, although marginally not significantly so $(P=0.08)$. This suggests that the non-significant trend $(P=0.19)$ for an increased level of cloacal microparasite richness with polygamy shown in Table 4, may be at least partially explained by body size effects. Given the low level of statistical significance of the results, however, this effect does not seem to be very important.

Evolutionary trends towards increased sexual dichromatism are marginally associated with evolutionary trends towards decreased microparasite richness $(P=0.08)$. This result would be expected if sexually dichromatic species have either a better immune system that defends them against infection by various microparasitic taxa and/or have evolved mate choice behaviour that prevents them from being infected in the first place.

Although evolutionary trends towards increased cloacal microparasite richness are associated with evolutionary trends towards increased cloacal microparasite prevalence, the association is marginally non-significant $(P=0.10)$.
If cloacal microparasites are mainly transmitted via the sexual route, then we would expect that both prevalence and richness would be higher during mating periods of the year. For the species that were sampled during both mating and non-mating periods (note that in some pairings either the "mating" or the "non-mating" period, but obviously not both, may have been represented by year-round data, see Table 2) the difference in both prevalence and richness is not significant (Wicoxon signed rank test: $P=0.15$ for prevalence and $P=0.26$ for richness). Moreover, if anything, the qualitative trend for both variables is for the non-mating periods of the year to be associated with higher cloacal microparasite prevalence and richness values than mating periods (see Table 2).

\section{DISCUSSION}

The main objective of this work was to answer the question of whether cloacal microbes are distributed across host species in a manner expected from the action of mechanisms of sexual transmission. The results of the comparative analysis indicate that the answer is "to some extent". 
Table 3. List of the Potentially Pathogenic Microorganisms Found in the Avian Cloaca that were Included in the Analyses (see Table 2 for References).

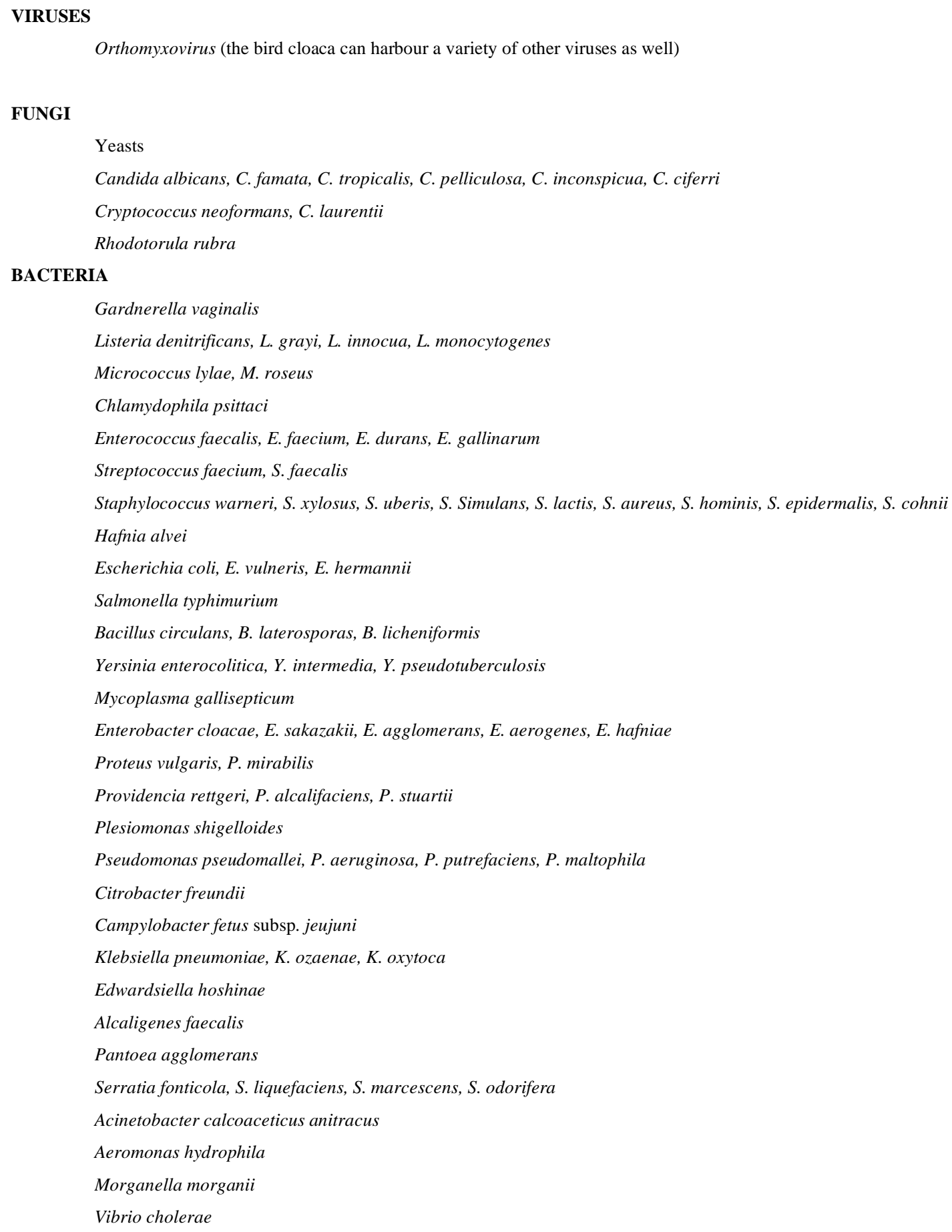

Some authors also mention broader categories of taxa such as fungi, yeast, anaerobic bacteria, aerobic bacteria, non-lactose fermenters, dark lactose fermenters, red lactose fermenters, coliforms. In addition, authors who do identify microorganism taxa in more detail may sometimes limit their identification to the Genus level. In this work this was the case for: Candida sp., Kloeckeria sp. among the yeasts and Clostridium sp., Listeria sp., Micrococcus sp., Chlamydia sp., Streptococcus sp., Staphylococcus sp., Corynebacterium sp., Salmonella sp., Bacillus sp., Yersinia sp., Mycoplasma sp., Enterobacter sp., Proteus sp., Providencia sp., Pseudomonas sp., Citrobacter sp., Campylobacter sp., Klebsiella sp., Pasteurella sp., Pantoea sp., Serratia sp. among the bacteria. Cases of infection reported in this manner were also included in the analyses.

Polygamy was expected to be associated with higher levels of richness of parasitic taxa and prevalence than mating systems characterized by more monogamous behaviour. The trends in the results are all in the expected direction, but they are not statistically significant (Table 4). The same qualita- tive, but non-significant results were obtained for the positive correlation between levels of EPCs and both richness and prevalence of cloacal microparasites (Table 4).

Sexual dichromatism is expected to be associated with both polygamy and EPCs, which is what I found if we just 
Table 4. Results of Correlations Between Phylogenetically Independent Contrasts of a Series of Parasitological, Morphological and Life-History Variables in Birds

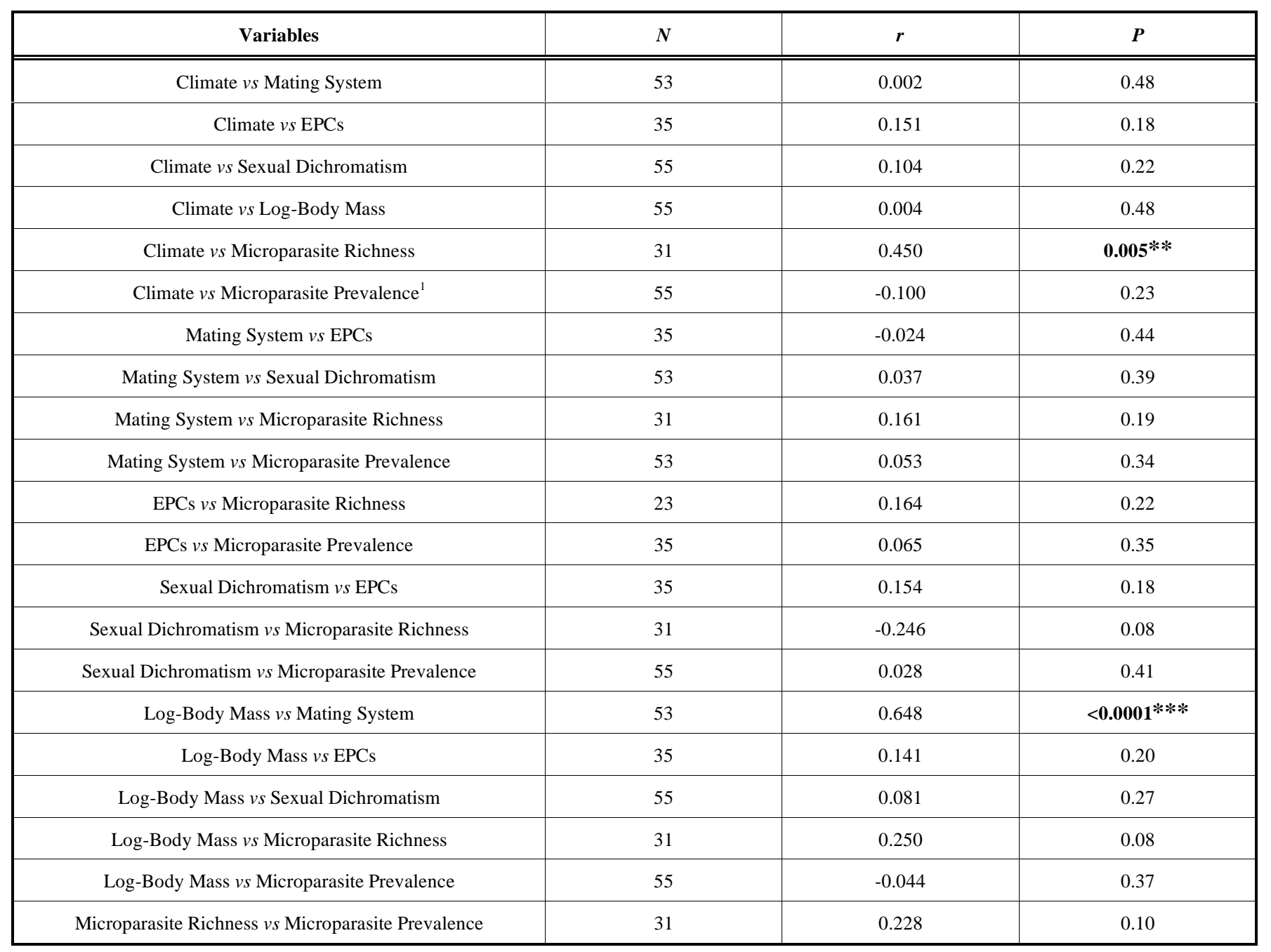

${ }^{1}$ In fact, square root (plus one)-corrected prevalence.

look at the trends shown in Table 4 , but those trends are not statistically significant. However, they are consistent with the non-significant trend for microparasite prevalence to be positively associated with sexual dichromatism. Together these results suggest that as species evolve polygamy, EPCs and sexual dichromatism, that is, as the evolution of the host species is driven more and more by sexual selection, then evolutionary changes may also occur that could result in higher prevalence values of cloacal microparasites. This is a result that is consistent with both the facilitiation of transmission of cloacal micropathogens under polygamy and also the evolution of host's counter-adaptations that tend to limit the risk of infection during sexual intercourse. Polygamy and EPCs may increase the risk, but honest sexually selected signals may decrease it. Whether those signals may also be manipulated by the parasite in order to facilitate its transmission is certainly a possibility especially in the case of the less virulent species and/or strains. At this stage, however, these possibilities remain speculative, requiring more detailed tests than the one I carried out here.

The results for richness of cloacal microparasitic taxa complement the above results in that although sexual di- chromatism is marginally non-significantly $(P=0.08)$ and negatively correlated with microparasite richness, a convex quadratic relationship is even better able to fit the data $\left(r^{2}=\right.$ $0.12, P=0.02$ ). This means that higher levels of cloacal microparasite richness can be associated with either very low or very high levels of sexual dichromatism, but not so much with intermediate levels of sexual dichromatism. What can explain such a pattern? Perhaps the ability to recognise infected sexual partners is low in monochromatic species, whereas in highly dichromatic species, although such ability may be higher, the effects of EPCs, polygamy or both may nonetheless increase transmission rate and host invasion by many different parasitic taxa.

A matched-pair analysis between mating and non-mating periods of the year for both prevalence and richness of cloacal microparasites indicated that there is a nonsignificant trend for those parasitological values to be higher during non-mating periods. This clearly suggests that broad studies of the cloacal microflora - that includes both taxa that may be more specialised on the reproductive system and those that may be more specialised on the digestive system although useful at the initial stages of a research program, 
may be too coarse to detect the fine adaptations expected between hosts and sexually transmitted parasites. Such adaptations are more likely to be detected in host-parasite systems involving specialist sexually transmitted micropathogens such as Chlamydia, Mycoplasma and others. Future empirical studies should focus on those more specialised taxa.

\section{CONCLUSION}

Although comparative tests of the kind performed here have their limitations with regard to the quality of the data being utilised, they remain the chief approach to explore broad evolutionary trends in the evolution of specific traits and to test adaptive hypotheses in a phylogenetic perspective. In addition, comparative analyses have an exploratory function that allows the fine tuning of subsequent observational or experimental research. Although in the present study only a handful of correlations were statistically significant, some interesting trends have been uncovered. Most importantly, cloacal microparasites are affected by and may in turn affect the dynamics of sexual selection as it unfolds during the evolution of mating systems, secondary sexual traits and mate choice. On the other hand, the extent to which sexually transmissible cloacal microparasites are capable of directly modifying host secondary sexual traits and behaviour in order to enhance their probability of transmission is an area that remains poorly explored, and it should be studied experimentally using specialist ST-micropathogens.

\section{ACKNOWLEDGMENTS}

I am very grateful to Pete Thrall for his shrewd comments on an earlier version of the manuscript and to The Open Ornithology Journal for publishing this special issue.

\section{REFERENCES}

[1] Anderson RM, May RM. Infectious diseases of humans: dynamics and control. Oxford: Oxford University Press 1991

[2] Anderson RM, May RM, Joysey K, et al. The invasion, persistence and spread of infectious diseases within animal and plant communities. Phil Trans R Soc Lond Biol Sci 1986; 314: 533-70.

[3] May RM, Anderson RM. Epidemiology and genetics in the coevolution of parasites and hosts. Proc R Soc Lond B 1983; 219: 281313.

[4] Smith G, Dobson AP. Sexually transmitted diseases in animals. Parasitol Today 1992; 8: 159-66.

[5] Ewald PW. Evolution of infectious disease. Oxford: Oxford University Press 1994.

[6] Thrall PH, Antonovics J. Polymorphism in sexual versus nonsexual disease transmission. Proc Biol Sci 1997; 264: 581-7.

[7] Thrall PH, Antonovics J, Wilson WG. Allocation to sexual vs nonsexual disease transmission. Am Nat 1998; 151: 29-45.

[8] May RM, Anderson RM. Population biology of infectious diseases: Part II. Nature 1979; 280: 455-61.

[9] Antonovics J, Iwasa Y, Hassell MP. A generalized model of parasitoid, venereal, and vector-based transmission processes. Am Nat 1995; 145: 661-75.

[10] Lombardo MP. On the evolution of sexually transmitted diseases in birds. J Avian Biol 1998; 29: 314-21.

[11] Hamilton WD, Zuk M. Heritable true fitness and bright birds: a role for parasites? Science 1982; 218: 384-7.

[12] Sheldon BC. Sexually transmitted disease in birds: occurrence and evolutionary significance. Phil Trans Biol Sci 1993; 339: 491-7.

[13] Knell RJ. Sexually transmitted disease and parasite-mediated sexual selection. Evolution 1999; 53: 957-61.

[14] Zahavi A. Mate selection - a selection for a handicap. J Theoret Biol 1975; 53: 205-14.
[15] Thrall PH, Antonovics J, Bever JD. Sexual transmission of disease and host mating systems: within-season reproductive success. Am Nat 1997; 149: 485-506.

[16] Anderson RM, Garnett GP. Mathematical models of the transmission and control of sexually transmitted diseases. Sexual Trans Dis 2000; 27: 636-43.

[17] Able DJ. The contagion indicator hypothesis for parasite-mediated sexual selection. Proc Natl Acad Sci USA 1995; 93: 2229-33.

[18] Lockhart AB, Thrall PH, Antonovics J. Sexually transmitted diseases in animals: ecological and evolutionary implications. Biol Rev1996; 71: 415-71.

[19] Hamilton WD. Mate choice near or far. Am Zool 1990; 30: 341 52.

[20] Holland B, Rice WR. Chase-away sexual selection: antagonistic seduction versus resistance. Evolution 1998; 52: 1-7.

[21] Graves BM, Duvall D. Effects of sexually transmitted diseases on heritable variation in sexually selected systems. Anim Behav 1995; 50: 1129-31.

[22] Poiani A. Sperm competition promoted by sexually transmitted pathogens and female immune defences. Ethol Ecol Evol 2002; 14 327-40.

[23] Poiani A. Complexity of seminal fluid: a review. Behav Ecol Sociobiol 2006; 60: 289-310.

[24] Kulkarni S, Heeb P. Social and sexual behaviours aid transmission of bacteria in birds. Behav Process 2007; 74: 88-92.

[25] Hoop RK. Transmission of chicken anaemia virus with semen. Vet Rec 1993; 133: 551-2.

[26] Halvorson DA. The control of H5 or H7 mildly pathogenic avian influenza: a role for inactivated vaccine. Avian Pathol 2002; 31: 512 .

[27] Tomczyk G, Minta Z. Elimination of Mycoplasma from the turkey semen. Bull Vet Inst Pulawy 2002; 46: 11-15.

[28] Buntz B, Bradbury JM, Vuillaume A, Rousselot-Paillet D. Isolation of Mycoplasma gallisepticum from geese. Avian Pathol 1986; 15: 615-7.

[29] Mohamed YS, Bohl EH. Studies on the transmission of Mycoplasma meleagridis. Avian Dis 1967; 11: 634-41.

[30] Lombardo MP, Thorpe PA. Microbes in tree swallow semen. J Wildl Dis 2000; 36: 460-8.

[31] Hupton G, Portocarrero S, Newman M, Westneat DF. Bacteria in the reproductive tracts of Red-winged Blackbirds. Condor 2003 105: 453-64.

[32] Westneat DF, Rambo TB. Copulation exposes female red-winged blackbirds to bacteria in male semen. J Avian Biol 2000; 31: 1-7.

[33] Marjánková K, Křivanec K, Zajiček J. Mass occurrence of necrotic inflammation of the penis in ganders caused by phytomycetes. Mycopathology 1978; 66: 21-26.

[34] Guarro J, Gene J, Stchigel AM. Developments in fungal taxonomy. Clin Microbiol Rev 1999; 12: 454-500.

[35] Szép I, Pataky M, Nagy G. The infectious cloaca-inflammation of the geese. International symposium on feeding and hygiene of Goose. Budapest: Hungary 1971; p. 44.

[36] Beemer AM, Kuttin ES, Katz Z. Epidemic venereal disease due to Candida albicans in geese in Israel. Avian Dis 1973; 17: 639-49.

[37] Stipkovits L, Varga Z, Czifra G, Dobos-Kovács M. Occurrence of mycoplasmas in geese affected with inflammation of the cloaca and phallus. Avian Pathol 1986; 15: 289-99.

[38] Hussong D, Damare JM, Limpert RJ, Sladen WJL, Weiner RM, Colwell RR. Microbial impact of Canada geese (Branta canadensis) and Whistling swans (Cygnus columbianus columbianus) on aquatic ecosystems. Appl Environ Microbiol 1979; 37: 14-20.

[39] Lucas FS, Heeb P. Environmental factors shape cloacal bacterial assemblages in great tit Parus major and blue tit $P$. caeruleus nestlings. J Avian Biol 2005; 36: 510-6.

[40] van Dijk A, Veldhuizen EJA, Haagsman HP. Avian defensins. Vet Immune Immunopathol 2008; 124: 1-18..

[41] Fuller R. Microbial activity in the alimentary tract of birds. Proc Nutr Soc 1984; 43: 55-61.

[42] Hillgarth N. Ectoparasite transfer during mating in ring-necked pheasants Phasianus colchicus. J Avian Biol 1996; 27: 260-2.

[43] van Loock M, Loots K, van Heerden M, Vanrompay D, Goddeeris BM. Exacerbation of Chlamydophila psittaci pathogenicity in turkeys superinfected by Escherichia coli. Vet Res 2006; 37: 745-55.

[44] El Tayeb AB, Hanson RP. Interactions between Escherichia coli and newcastle disease virus in chickens. Avian Dis 2002; 46: 6607 . 
[45] Moreno J, Briones V, Merino S, Ballesteros C, Sanz JJ, Tomás G. Beneficial effects of cloacal bacteria on growth and fledging size in nestling pied flycatchers (Ficedulahy poleuca) in Spain. Auk 2003; 120: 784-90.

[46] Weinack OM, Snoeyenbos GH, Soerjadi-Liem AS. Further studies on competitive exclusion of Salmonella typhimurium by lactobacilli in Chickens. Avian Dis 1985; 29: 1273-6.

[47] Lombardo MP, Thorpe PA, Power HW. The beneficial sexually transmitted microbe hypothesis of avian copulation. Behav Ecol 1999; 10: 333-50.

[48] La Ragione RM, Casula G, Cutting SM, Woodward MJ. Bacillus subtilis spores competitively exclude Escherichia coli O78:K80 in poultry. Vet Microbiol 2001; 79: 133-42.

[49] La Ragione RM, Woodward MJ. Competitive exclusion by Bacillus subtilis spores of Salmonella enterica serotype enteritidis and Clostridium perfringens in young chickens. Vet Microbiol 2003; 94: 245-56.

[50] Peel MC, Finlayson BL, McMahon TA. Updated world map of the Köppen-Geiger climate classification. Hydrol Earth Syst Sci 2007; 11: 1633-44.

[51] Felsenstein J. Phylogenies and the comparative method. Am Nat 1985; 43: 300-11.

[52] Midford PE, Garland T Jr, Maddison WP. PDAP package of mesquite. Version 1.07. 2005

[53] Maddison WP, Maddison DR. mesquite: a modular system for evolutionary analysis. Version 1.1 2006; available at: http://mesquiteproject.org

[54] Grafen A. The phylogenetic regression. Phil Trans R Soc Lond B 1989; 326: 119-57.

[55] Livezey BC, Zusi RL. Higher-order phylogeny of modern birds (Therapoda, Aves: Neornithes) based on comparative anatomy. II. Analysis and discussion. Zool J Linn Soc 2007; 149: 1-95.

[56] Johnson KP, Sorenson MD. Phylogeny and biogeography of dabbling ducks (Genus: Anas): a comparison of molecular and morphological evidence. Auk 1999; 116: 792-805.

[57] Donne-Goussé C, Laudet V, Hänni C. A molecular phylogeny of anseriformes based on mitochondrial DNA analysis. Mol Phylog Evol 2002; 23: 339-56.

[58] Kimball RT, Braun EL. A multigene phylogeny of galliformes supports a single origin of erectile ability in non-feathered facial traits. J Avian Biol 2008; 39: 438-45.

[59] Paton TA, Baker AJ, Groth JG, Barrowclough GF. RAG-1 sequences resolve phylogenetic relationships within Charadriiform birds. Mol Phylogenet Evol 2003; 29: 268-78.

[60] Thomas GH, Wills MA, Székely T. A supertree approach to shorebird phylogeny. BMC Evol Biol 2004; 4: p. 28.

[61] Lerner HRL, Mindell DP. Phylogeny of eagles, old world vultures, and other accipitridae based on nuclear and mitochondrial DNA. Mol Phylogenet Evol 2005; 37: 327-46.

[62] Sibley CG, Ahlquist JE. The phylogeny and classification of the australo-papuan passerine birds. EMU 1985; 85: 1-14.

[63] Björklund M. Coming of age in fringillid birds: heterochrony in the ontogeny of secondary sexual characters. J Evol Biol 1991; 4: 8392.

[64] Carson RJ, Spicer GS. A phylogenetic analysis of the emberizid sparrows based on three mitochondrial genes. Mol Phylogenet Evol 2003; 29: 43-57.

[65] Ericson PGP, Irestedt M, Johansson US. Evolution, biogeography, and patterns of diversification in passerine birds. J Avian Biol 2003; 34: 3-15.

[66] Ericson PGP, Johansson US. Phylogeny of passerida (aves: passeriformes) based on nuclear and mitochondrial sequence data. Mol Phylogenet Evol 2003; 29: 126-38.

[67] Cadena CD, Cuervo AM, Lanyon SM. Phylogenetic relationship of the red-bellied grackle (Icteridae: Hypopyrrhus pyrohypogaster) inferred from mitochondrial DNA sequence data. Condor 2004; 106: 664-70.

[68] Gill FB, Slikas B, Sheldon FH. Phylogeny of titmice (paridaew): II. species relationships based on sequences of the mitochondrial cytochrome- $B$ gene. Auk 2005; 122: 121-43.

[69] van der Meij MAA, De Bakker MAG, Bout RG. Phylogenetic relationships of finches and allies based on nuclear and mitochondrial DNA. Mol Phylogenet Evol 2005; 34: 97-105.

[70] Alström P, Olsson U, Lei F, Wang H-T, Gao W, Sunberg P. Glyn Phylogeny and classification of the Old World Emberizini (aves, passeriformes). Mol Phylogenet Evol 2008; 47: 960-73.
[71] Treplin S, Siegert R, Bleidorn C, Thompson HS, Fotso R, Tiedemann R. Molecular phylogeny of songbirds (aves: passeriformes) and utility of common nuclear marker loci. Cladistics 2008; 24: 328-49.

[72] Johansson US, Fjeldså J, Bowie RCK. Phylogenetic relationships within passerida (aves: passeriformes): a review and a new molecular phylogeny based on three nuclear intron markers. Mol Phylogen Evol 2008; 48: 858-76.

[73] Møller AP. Mating systems among european passerines: a review. Ibis 1986 ; 128: 234-50.

[74] Cordero P, Wetton JH, Parkin DT. Extra-pair paternity and male badge size in the house sparrow. J Avian Biol 1999; 30: 97-102.

[75] Stewart R, Rambo TB. Cloacal microbes in house sparrows. Condor 2000; 102: 679-84

[76] Animal diversity web. University of Michigan, museum of zoology 2009. available at: http://animaldiversity.ummz.umich.edu.

[77] Archbold M, Poiani A, Browning G. Escherichia coli infection in house sparrows: are there implications for sexual selection? Avocetta $2005 ; 29$ : 85-9.

[78] Rogers KH. Prevalence of pathogenic enteric bacteria in wild birds associated with agriculture in Humboldt county. California: MSc Thesis, CA, USA. Humboldt State University 2006.

[79] Rollin PE, Baylet R, Johnson AR. Intestinal microflora of young greater flamingos (Phoenicopterus ruber roseus Pallas) in the Camargue. J Wildl Dis 1983; 19: 61-2.

[80] Poiani A, Dixson A. Animal homosexuality: a biosocial perspective. Cambridge: Cambridge University Press in preparation. for publication in 2010 .

[81] Cezilly F, Johnson AR. Re-mating between and within breeding seasons in the greater flamingo Phoenicopterus ruber roseus. Ibis 1995; 137: 543-6.

[82] Williams L. Breeding behaviour of the brewer blackbird. Condor 1952; 54: 3-47

[83] Horn HS. Social behaviour of nesting brewer's blackbirds. Condor 1970; 72: 15-23.

[84] Yokel DA, Rothstein SI. The basis for female choice in an avian brood parasite. Behav Ecol Sociobiol 1991; 29: 39-45.

[85] Strausberger BM, Ashley MV. Breeding biology of brood parasitic brown-headed cowbirds (Molothrus ater) characterized by parentoffspring and sibling-group reconstruction. Auk 2003; 120: 433-45

[86] Smith HG, von Schantz T. Extra-pair paternity in the European starling: the effect of polygyny. Condor 1993; 95: 1006-15.

[87] Olsen B, Munster VJ, Wallensten A, Waldenström J, Osterhaus ADME, Fouchier RAM. Global patterns of influenza: a virus in wild birds. Science 2006; 312: 384-8.

[88] Westneat DF. Polygyny and extrapair fertilization in eastern redwinged blackbirds (Agelaius phoeniceus). Behav Ecol 1993; 4: 49. 60 .

[89] Sherman PW, Morton ML. Extra-pair fertilizations in the mountain white-crowned sparrows. Behav Ecol Sociobiol 1988; 22: 413-20.

[90] Poiani A. Ectoparasitism as a possible cost of social life: a comparative analysis using Australian passerines (passeriformes). Oecologia 1992; 92: 429-41.

[91] Conrad KF, Clarke MF, Robertson RJ, Boag PT. Paternity and the relatedness of helpers in the cooperatively breeding bell miner. Condor 1998; 100: 343-9.

[92] Poiani A, Wilks C. Cloacal microparasites and sexual selection in three Australian passerine species. Ethol Ecol Evol 2000; 12: 2518 .

[93] Mulder RA, Dunn PO, Cockburn A, Lanzenby-Cohen KA, Howell MJ. Helpers liberate female fairy-wrens from constraints on extrapair mate choice. Proc R Soc Biol Sci 1994; 255: 223-9.

[94] Poiani A, Gwozdz J. Cloacal microorganisms and mating systems of four Australian bird species. EMU 2002; 102: 291-6.

[95] Wittingham LA, Dunn PO, Magrath RD. Relatedness, polyandry and extra-group paternity in the cooperatively-breeding whitebrowed scrubwren (Sericornis frontalis). Behav Ecol Sociobiol 1997; 40: 261-70.

[96] Higgins PJ, Peter JM, Steele WK, Eds. Handbook of Australian, new Zealand and Antarctic birds. Tyrant-flycatchers and chats. Australia: Oxford University Press 2001; vol.5.

[97] Milne RJ, Poiani A, Coulson G, Auld R. Faecal Escherichia coli and Chlamydophila psittaci in the superb lyrebird Menura novaehollandiae: host sex and age effects. Acta Ornithol 2004; 39: 111 20. 
[98] Feekes F. The black-bellied whistling duck in mexico - from traditional use to sustainable management? Biol Cons 1991; 56: 123-31.

[99] Aguirre AA, Quan TJ, Cook RS, McLean RG. Cloacal flora isolated from wild black-bellied whistling ducks (Dendrocygna autumnalis) in Laguna La Nacha, Mexico. Avian Dis 1992; 36: 459-62.

[100] Allen CR. Predictors of introduction success in the South Florida avifauna. Biol Inv 2006; 8: 491-500.

[101] Scott DK, Clutton-Brock TH. Mating systems, parasites and plumage dimorphism in waterfowl. Behav Ecol Sociobiol 1990; 26: 26173.

[102] Cafarchia C, Romito D, Iatta R, Camarda A, Montagna MT, Otranto D. Role of birds of prey as carriers and spreaders of Cryptococcus neoformans and other zoonotic yeasts. Med Mycol 2006b; 44: 485-92.

[103] Luechtefeld NAW, Blaser MJ, Reller LB, Wang W-L L. Isolation of Campylobacter fetus subsp. jejuni from migratory waterfowl. J Clin Microbiol 1980; 12: 406-8.

[104] Dubowy PJ. Northern shoveler (Anas clypeata). the birds of North America online. Poole A, Ed. Ithaca: Cornell Lab of Ornithology. retrieved from the Birds of North American 1996; Online: http://bna.cornell.edu/bna/species/217 . doi:10.2173/bna.217

[105] Cocker CR, McKinney F, Hays H, Briggs SV, Cheng KM. Intromittent organ morphology and testis size in relation to mating system in waterfowl. Auk 2002; 119: 403-13.

[106] Fukushima H, Gomyoda M. Intestinal carriage of Yersinia pseudotuberculosis by wild birds and mammals in Japan. Appl Environ Microbiol 1991; 57: 1152-5.

[107] McKinney F, Stolen P. Extra-pair bond courtship and forced copulation among captive green-winged teal Anas crecca carolinensis. Anim Behav 1982; 30: 461-74.

[108] Johnson WP, Rohwer FC. Pairing chronology and agonistic behaviours of wintering green-winged teal and mallards. Wilson Bull 1998; 110: 311-5

[109] Figuerola J, Green AJ. A comparative study of egg mass and clutch size in the Anseriformes. J Ornithol 2006; 147: 57-68.

[110] Møller AP, Erritzøe J. Host immune defence and migration in birds. Evol Ecol 1998; 12: 945-53.

[111] Mitchell C. Re-mating in migratory Wigeon Anas penelope. Ardea 1997; 85: 275-7.

[112] Pearce A. Displays of the garganey Anas querquedula: evidence of multiple functions. Wildfowl 2000; 51: 83-101.

[113] Peters J, Brewer G, Bowe LM. Extrapair paternity and breeding synchrony in gadwalls (Anas strepera) in North Dakota. Auk 2003; 120: 883-8.

[114] Lombardo MP, Thorpe PA, Cichewicz R, et al. Communities of cloacal bacteria in tree swallow families. Condor 1996; 98: 167-72.

[115] Mougeot F. Breeding density, cuckoldry risk and copulation behaviour during the fertile period in raptors: a comparative analysis. Anim Behav 2004; 67: 1067-76.

[116] Cafarchia C, Camarda A, Romito D, et al. Occurrence of yeasts in cloacae of migratory birds. Mycopathology 2006a; 161: 229-34.

[117] Lamberski N, Hull AC, Fish AM, Beckmen K, Morishita TY. A survey of the choanal and cloacal aerobic bacterial flora in freeliving and captive red-tailed hawks (Buteo jamaicensis) and Cooper's hawks (Accipiter cooperii). J Avian Med Surg 2003; 17: 1315.

[118] Hobbs R, DeStefano S. Breeding biology and nest-site selection of red-tailed hawks in an altered desert grassland. J Raptor Res 2006; 40: $38-45$

[119] Prange HD, Anderson JF, Rahn H. Scaling of skeletal mass to body mass in birds and mammals. Am Nat 1979; 113: 103-22.

[120] Negro JJ, Donázar JA, Hiraldo F. Copulatory behaviour in a colony of lesser kestrels: sperm competition and mixed reproductive strategies. Anim Behav 1992; 43: 921-30.

[121] Sharpe RB. Contributions to a history of the Accipitres. The Genus Glaucidium. Ibis $1875 ; 17$ : 35-59.

[122] Tella JL. Polyandrous trios in a population of Egyptian vultures (Neophron percnopterus). J Raptor Res 1993; 27: 119-20.

[123] Donázar JA, Ceballos O, Tella JL. Copulation behaviour in the Egyptian vulture Neophron percnopterus. Bird Study 1994; 41: 3741.

[124] Blanco G, Lemus JA, Grande J, et al. Geographical variation in cloacal microflora and bacterial antibiotic resistance in a threatened avian scavenger in relation to diet and livestock farming practices. Environ Microbiol 2007; 9: 1738-49.
[125] Marsh RL, Storer RW. Correlation of flight-muscle size and body mass in Cooper's hawks: a natural analogue of power training. J Exp Biol 1981; 91: 363-8.

[126] Bielefeldt J, Rosenfield RN, Cary J. Copulatory and other preincubation behaviours of Cooper's Hawks. Wilson Bull 1991; 103 . 656-60.

[127] Rosenfield RN, Bielefeldt J. Cooper's Hawk (Accipiter cooperii) No. 75 in: the birds of North America . Poole A, Gill F, Eds. Washington DC: academy of natural sciences, Philadelphia PA: The American Ornithologists' Union 1993.

[128] Rosenfield RN, Driscoll TG, Franckowiak RP, Rosenfield LJ, Sloss BL, Bozek MA. Genetic analysis confirms first record of polygyny in Cooper's hawks. J Raptor Res 2007; 41: 230-4.

[129] Kapperud G, Rosef O. Avian wildlife reservoir of Campylobacter fetus subsp. jejuni, Yersinia spp., and Salmonella spp. in Norway. Appl Environ Microbiol 1983; 45: 375-80.

[130] Korpimäki E. Mating system and mate choice of Tengmalm's owls Aegolius funereus. Ibis 1989; 131: 41-50.

[131] Hakkarainen H, Korpimäki E, Ryssy J, Vikström S. Low heritability in morphological characters of Tengmalm's owls: the role of cyclic food and laying date? Evol Ecol 1996; 10: 207-19.

[132] Creelman E, Storey AE. Sex differences in reproductive behaviour of Atlantic puffins. Condor 1991; 93: 390-8.

[133] Griffith SC, Owens IPF, Thuman KA. Extrapair paternity in birds: a review of interspecific variation and adaptive function. Mol Ecol 2002; 11: 2195-2212.

[134] González Solís J, Sokolov E, Becker PH. Courtship feedings, copulations and paternity in common terns, Sterna hirundo. Anim Behav 2001; 61: 1125-32.

[135] Ludwigs J.-D. A case of cooperative polyandry in the common tern. Waterbirds 2004; 27: 31-4

[136] Polo V, Carrascal LM. Shaping the body mass distribution of passeriformes: habitat use and body mass are evolutionarily and ecologically related. J Anim Ecol 1999; 68: 324-37.

[137] Garamszegi LZ, Pavlova DZ, Eens M, Møller AP. The evolution of song in female birds in Europe. Behav Ecol 2007; 18: 86-96.

[138] Janiga M, Sedlarova A, Rigg R, Novotna M. Patterns of prevalence among bacterial communities of alpine accentors (Prunella collaris) in the Tatra mountains. J Ornithol 2007; 148: 135-43.

[139] Holzinger-Umlauf H A-M, Marschang RE, Gravendyck M, Kaleta EF. Investigation on the frequency of Chlamydia sp. infections in tits (Paridae). Avian Pathol 1997; 26: 779-89.

[140] Smith HG. Parental age and reproduction in the Marsh Tit Parus palustris. Ibis 1993; 135: 196-201.

[141] Lilliendahl K. Daily patterns of body mass gain in four species of small wintering birds. J Avian Biol 2002; 33: 212-8.

[142] Brittingham MC, Temple SA, Duncan RM. A survey of the prevalence of selected bacteria in wild birds. J Wildl Dis 1988; 24: 299307.

[143] Gray DA. Carotenoids and sexual dichromatism in North American passerine birds. Am Nat 1996; 148: 453-80.

[144] Chandler CR, Ketterson ED, Nolan V, Jr, Ziegenfus C. Effects of testosterone on spatial activity in free-ranging male dark-eyed juncos, Junco hyemalis. Anim Behav 1994; 47: 1445-55.

[145] Petrie M, Doums C, Møller AP. The degree of extra-pair paternity increases with genetic variability. Proc Natl Acad Sci USA 1998; 95: 9390-5

[146] Mateos C. Sexual selection in the ring-necked pheasant: a review. Ethol Ecol Evol 1998; 10: 313-32.

[147] Papeschi A, Briganti F, Dessì-Fulgheri F. Winter androgen levels and wattle size in male common pheasants. Condor 2000; 102: 193-7.

[148] Garamszegi LZ, Eens M, Hurtrez-Boussès S, Møller AP. Testosterone, testes size, and mating success in birds: a comparative study. Horm Behav 2005; 47: 389-409.

[149] Fritz BA, Thomas CB, Yuill TM. Serological and microbial survey of Mycoplasma gallisepticum in wild turkeys (Meleagris gallopavo) from six western states. J Wildl Dis 1992; 28: 10-20.

[150] Casanovas L, de Simon M, Ferrer MD, Arques J, Monzon G. Intestinal carriage of campylobacters, salmonellas, yersinias and listerias in pigeons in the city of Barcelona. J Appl Bacteriol 1995; 78: 11-13.

[151] Schleucher E. Energy metabolism in an obligate frugivore, the superb fruit dove (Ptilinopus superbus). Aust J Zool 1999; 47: 16979. 
[152] Szekely T, Reynolds JD, Figuerola J. Sexual size dimorphism in shorebirds, gulls, and alcids: The influence of sexual and natural selection. Evolution 2000; 54: 1404-13.

[153] Rodríguez-Teijeiro JD, Puig Cerver M, Gallego S, Cordero PJ, Parkin DT. Pair bonding and multiple paternity in the polygamous common quail Coturnix coturnix. Ethology 2003; 109: 291-302.

[154] Amano T, Yamaura Y. Ecological and life-history traits related to range contractions among breeding birds in Japan. Biol Cons 2007; 137: $271-82$
[155] Broman T, Bergström S, On SLW, et al. Isolation and characterization of Campylobacter jejuni subsp. jejuni from Macaroni Penguins (Eudyptes chrysolophus) in the subantarctic region. Appl Environ Microbiol 2000; 66: 449-52.

[156] Immerman RS. Sexually transmitted disease and human evolution: survival of the ugliest? Human Ethol Newslett 1986; 4: 6-7.

Received: May 10, 2009

Revised: June 15, 2009

Accepted: June 16, 2009

(C) Aldo Poiani.; Licensee Bentham Open.

This is an open access article licensed under the terms of the Creative Commons Attribution Non-Commercial License (http://creativecommons.org/licenses/_by-nc/3.0/) which permits unrestricted, non-commercial use, distribution and reproduction in any medium, provided the work is properly cited. 